\title{
Grosslinguistic Influence of the First Language: Interlingual errors in the writing of ESL Saudi learners
}

\author{
Fawaz Ali Ahmed Qasem * \\ (University of Bisha, Kingdom of Saudi Arabia)
}

\begin{abstract}
Writing as a productive skill is challenging for the learners as it requires rich linguistic and cognitive abilities to match words with ideas well. A learner of any language as Second Language (SL), for example English, Arabic, Chinese, or German, enters an early, natural, and inevitable stage of making various errors in writing compositions. The errors could be due to dissimilar linguistic systems of the two languages (L1 and L2) or the lack of understanding the SL linguistic rules. This study focuses on investigating the frequent and common inter-lingual errors (the negative influence) committed by Arabic-speaking learners of English as Second Language (ESL). The study is based on Error Analysis (EA) of the essays of a group of English major undergraduate students from the University of Bisha, Al-Namas, Saudi Arabia. Contrastive Analysis Hypothesis (CAH) is included to predict most of the errors in the collected samples. The findings of the study show that common errors in the data are interlingual (54.03\%). The errors within the Grammatical Category include the misuse of tenses, dropping the subjects, dropping verb to be-copular and word order misplacement. The majority of errors in the study are due to the interference of L1 linguistic system including the different orthographic, phonological, morpho-syntactic components. For instance, the participants' dropping subjects in English can be attributed to the fact that Arabic as L1 and as Null Subject Language (NSL), unlike English, allows subject drop. The results also find that within the Lexical Category, preposition and article errors are the most frequent errors and that spelling errors are the most dominant errors within the Mechanics Category. The study gives some pedagogical implications and suggestions to avoid and minimize the interlingual errors of such type. For instance, teachers need to focus more on enlightening their students about the contrastive
\end{abstract}

\footnotetext{
* Fawaz Ali Ahmed Qasem: Assistant Professor at Department of English, Bisha University, Kingdom of Saudi Arabia. He has taught English in various universities and institutions that of Ibb University, and University of Science and Technology, in Yemen. His research interests include: Linguistics, Applied Linguistics, First and Second Language Acquisition, Psycholinguistics, Sociolinguistics, Corpus Linguistics, Forensic Linguistics and English for Specific Purposes. E-mail: faqasem@ub.edu.sa, Fawazrajehbu@gmail.com.
} 
language systems from the early stage of learning ESL.

Keywords: English as second language, interlingual errors, error analysis, contrastive analysis

\section{Introduction}

It is commonly known that learners go through a natural stage where they make errors in their early period of learning any language as SL before being competent in L2. Studies existing in the literature have approved the influence of L1 on L2. The more differences in linguistic systems between L1 and L2, the more likely the occurrence of errors is. For instance, Chinese language is more difficult to learn compared to English for many learners who speak German or French because of its different and complex orthographic systems, but Chinese could be easy for the learners of Chinese as L2 who have languages with similar scripts like Chinese. English is widely known and most learned as L2 across the world but it still has different linguistic systems from many languages in the world. For instance, English has a contrastive linguistic system compared to Arabic, which we find is a Semitic with rich and complex morpho-syntactic and phonological systems while English is from Indo-European Germanic languages group. Based on Error Analysis (EA), it is shown that there is a stage where learners of ESL commit errors as a result of the influence of their L1 linguistic system and researchers refer to it as inter-language (Ellis, 1985). Arabic-speaking learners of ESL commit prominent interlingual errors derived from the linguistic differences of Arabic and English. The errors are due to the influence of Arabic as L1. This has been reported in some studies in the literature and will be addressed further in this study where we cover the errors in writing composition of Arabic-speaking learners of ESL.

\subsection{Literature review}

In the literature of ESL, errors have been looked at very early and in different styles. Some researchers have gone directly to test the errors and analyze them via Error Analysis (EA). In this regard, EA as a field deals with a critical look at the nature of errors in ESL. Richards \& Schmit (2002) define EA as a technique to identify, classify, and interpret the produced errors in a systematic way. There are many rich studies on EA in Arabic-speaking ESL context that attempted to account for and look at writing errors and the learners' weakness in this regard (Al-Sindy, 1994; Al-Kahtani, 2002; Al-Shahrani, 2004). Some other researchers dealt with errors by studying the different and similar linguistic systems of the two languages, L1 and L2. That is to say, they apply Contrastive Analysis Hypotheses (CAH), which focuses on the comparison of the linguistic systems of the two languages L1 and L2, to predict the errors based on the mother tongue interference, Richards \& Schmidt (2002). Interlanguage, Selnker's (1972) framework is another 


\section{Crosslingustic Influence of the First Language: Interlingual errors in the writing of ESL Saudi learners}

interesting existing attempt to account for the errors' stage of language learning. It says that learners enter a stage where they take and build a system from L1 and L2 which consist of a set of linguistic rules and this stage is referred to as interlanguage. Errors in language learning also have been looked in terms of transfer concept which started early in the framework of behaviouristic approach of language. Many researchers divided the transfer errors into, negative and positive transfer errors. Such types of errors are due to the similarity between L1 and L2 (Odlin, 1989) or due to the difficulty to linguistically distinguish between the first language and the second language (Lado, 1957). Negative transfer errors are caused due to the influence of the mother tongue of the learner and the positive transfer errors are due to the lack of understanding the linguistic rules of the target language (Gass \& Selinker, 1983). Interesting studies in Arabic have looked at similar concepts of transfer as in Al-Qadi (1992), Noor (1994), Al-Qadi (1997).

Over time, research scholars in the field of ESL have studied understanding and differentiating errors from mistakes. Errors, unlike mistakes, have to do with the lack of understanding of the rules and knowledge of the Second Language (Hubbard et al., 1983). The mistakes in Second Language are not serious compared to errors. Many researchers consider mistakes as 'slips' which may occur in the First Language of the learner or the Second Language which are caused when learners are confused (Harmer, 1983; Brown, 2000). Errors in learning any language are inevitable in language learning which are due to the mother tongue interference. Dulay et al. (1982), Larsen \& Long (1992), Brow (1993), Ellis (1997) found mistakes as slips which have to do with the performance where all native speakers of any language or the learners make mistakes that can be corrected. Errors are systematic and considered a deviation as a result of the learners' failure in mastering the rules of the target language.

Regarding the errors' taxonomy and the source of errors, Richards (1974) classified errors into two main categories: (a) Inter-lingual errors (Mother-tongue influence) are types of errors influenced by the native languages which interfere with target language learning, and (b) intra-lingual errors are types of errors caused by the target language itself. In this study, we focus mainly on the interlingual errors caused by Arab-speaking learners of English because such type of error is widely prevailing among the Arabic learners of English especially at the early stages of learning English. This happens where the learners are influenced by the Arabic linguistic system.

In the existing literature in the ESL context, there are interesting studies, with the similar context of this study, that attempted to present the classification of errors' types and to account for learners' errors through error analysis. Al-Jarf (2010) examined the spelling errors in Saudi Arabia context of collected writing essays corpora. Based on the classification of the spelling errors into three categories - (a) whole word errors, (b) faulty 


\section{Fawaz Ali Ahmed Qasem}

graphemes, and (c) faulty phonemes - the researcher found that spelling errors were interlingual and intralingual due to phonological and orthographic problems. In a quite similar context, Alhaysony (2012) explored the types of errors by female Saudi EFL students in their use of articles at the University of Hail. It was found that $57 \%$ of the errors were interlingually caused by the influence of Arabic as the native language of the participants. The most common error of interlingual errors was the addition of the definite article 'the' as it is more frequently used in Arabic. In a similar context, Mourssi's study (2013) on 74 Arab learners of English explored the cross-linguistic influence of L1 on learning L2. Linguistic items of 222 written texts produced by students from an Omani High School were analyzed. The results showed that the subjects had problems with the use of articles in English as influenced by their L1 which has different rules of article use from that of English. Mourssi also believed many errors concerning the verb to be, tenses, prepositions and the article system produced by learners in his study were caused by the native language.

Younes \& Albalawi (2015) explored the most common writing difficulties faced by 40 female English language and translation major sophomore students from Tabuk University, Saudi Arabia. Their findings showed that the most common problems in the students' writing samples were classified into three types: (a) grammatical problems such as tenses, prepositions, subject-verb agreement, and article use; (b) punctuation problems; (c) spelling problems such substitution, omission, and addition, disordering spelling error. The researchers said that, apart from the influence of Arabic as L1, some teachers' way of teaching English could be the reason behind writing errors such as using L1 more in teaching and not using the target language in various contexts.

On the basis of findings, there were many common errors attributed to the L1 interference with regard to the use of articles in English during the acquisition of ESL by Arab-speaking learners (Al-Qadi, 2017; Alhaisoni, Gaudel \& Al-Zuoud, 2017). Nuruzzaman, Islam \& Shuchi (2018) examined the writing errors in the paragraph writings of ninety Saudi non-English major undergraduate students from three different colleges of Medicine, Engineering, and Computer Science. They found that the majority of the grammatical errors were due to the influence of L1. Similarly, Hussain (2019) in her analysis of the errors in written English essays of female Saudi students, found that the learners made many grammatical and some other errors which had to do with spelling and punctuations. Recently, Kazazoğlu (2020) addressed the issue of L1 interference in foreign language writing using a contrastive error analysis of two groups: Turkish-speaking ESL learners and Arabic-speaking ESL learners. It was found that participants made various writing errors due to the mother tongue influence in terms of sentence structure: tenses, capitalization, word choice, and spelling errors. Qasem (2020) also examined the spelling 


\section{Crosslingustic Influence of the First Language: Interlingual errors in the writing of ESL Saudi learners}

errors of ESL Arabic-speaking learners in relation to the phonological syllable structure of words and found that spelling errors on the onset position were fewer compared to the nucleus and coda positions. The researcher showed that Arabic-speaking ESL learners make more spelling errors with tri-syllabic and complex words than that of mono-syllabic words. The study also explored that the spelling errors were due to the different orthographical and morpho-phonological systems of Arabic and English, for instance, the letter-to-sound correspondence, sound-to-letter correspondence and homophones. The researcher in the same study gave some reasons and justifications behind the learners' weakness in the writing skill in ESL. Al-Zoubi \& Abu-Eid (2014) and Lghzeel \& Radzuan (2020) looked at the influence of Arabic as L1 on the use of passive voice in learning and writing of ESL. It was found that Arabic-speaking students had a high rate of Arabic influence on errors in the English passive voice. Other studies have also significantly demonstrated the existence of the errors in the writing of the Arabic-speaking learners due to the different structure of L1 (Arabic) and L2 (as in Almahameed \& Al-Shaikhli, 2017; Khatter, 2019; Alkhudiry \& Al-Ahdal, 2020).

\subsection{Linguistic differences of $\mathrm{L} 1$ and $\mathrm{L} 2$}

The interlingual errors in the writings occur due to the interference of Arabic as First Language L1 on learning English as L2. In this regard, here, we give the reader some hints on the common and the different linguistic systems of both languages, Arabic and English, which lead the Arab learners to make such kind of errors. Arabic is a Semitic language like Hebrew and Amharic and has rich morpho-syntactic and phonological system, unlike English, which belongs to Indo-European language family.

Arabic and English have to a great extent different orthographic and phonological systems. The alphabetical scripts are written differently as they are from various language families. Arabic is written from right to left, unlike English. As for some morpho-syntactic categories, unlike English, Arabic has two contrast linguistic word-order VSO and SVO. We can say in Arabic, Ahmed yasharb al-maa 'Ahmed drinks water', and yasharab Ahmed al-maa ' 'drinks Ahmed water' whereas English allows one form when it comes to the order - that is SVO. An interesting difference between the two languages is that Arabic is null-subject language and English is non-null subject language ${ }^{\circledR}$. Arabic allows subjects to appear overtly or covertly attached to the verbs whereas English is non-null subject language where subjects always appear overtly. Another clear syntactic difference between Arabic and English is that Arabic has nominal clause and verbal clause - the nominal clauses in Arabic do not allow the copular -be to be there whereas in English there is an

\footnotetext{
(1) An interesting discussion on null subject languages and non-null subject languages check Holmberg (2010) and one can check the same phenomenon discussed in Arabic in, Fehri (1993), Aoun, Choueiri \& Benmamoun (2010), Saeed (2011), and Qasem (2014).
} 
example (1).

$$
\begin{array}{ll}
\text { (1) Ahmed } & \text { Talaabun } \\
\text { N-Ahmed } & \text { N-student } \\
\text { 'Ahmed is a student.' } &
\end{array}
$$

The difference between Arabic and English when it comes to the adjective placement is that, in Arabic the adjectives come after nouns as in (2) whereas in English, the adjectives come before nouns and 'be copular'.

$$
\begin{array}{ll}
\text { (2) Al-Shuqatu } & \text { kabeiratun } \\
\text { the- flat-N } & \text { big -Adj } \\
\text { 'The flat is Big.' } &
\end{array}
$$

One of the interesting lexical difference between Arabic and English is that there is only definite article, $\mathrm{Al}$ - (the) and no indefinite particles in Arabic, unlike English. Some Arabic-speaking learners of English generalize the use of the definite article in many positions of indefinite articles or they drop the indefinite articles. Many cross-linguistic studies on learners of ESL other than Arabic-speaking learners, have shown the interference of L1 in the process of learning ESL as in Hebrew-speaking learners (Hacohen \& Schaeffer, 2007), Turkish-speaking learners (Kırkgöz, 2010), Spanish-speaking learners (Urdaneta, 2011), and Chinese-speaking learners (Liu \& Xu, 2013).

\section{The method}

\subsection{Participants}

In this study, the participants were 94 male English major undergraduate students from the University of Bisha, Al-Namas, Saudi Arabia. The participants were mono-lingual speakers of Arabic who are learning English as a Foreign Language (FL). The data of the study were collected from 2-6 levels of classes, with the number of participants there in each class being limited. The participants were given the task of writing essays. The participants' age varied from 18 to 22 .

\subsection{The tools}

Basically, the data of this research were elicited from two sources: (a) writing composition essays, and (b) informal discussion and interview with teachers of English who had rich experience in TEFL context. The data were also collected in the classrooms before the COVID-19 breakout during face-to-face teaching. To ensure the validity of the writing topics of the essays given to the participants, two teachers checked the nature of the questions included in the study.

\subsection{The objectives of the study}

The study aims at identifying the most common and prevailing interlingual errors in the writing samples of undergraduate Arabic-speaking ESL learners majoring in English from 


\section{Crosslingustic Influence of the First Language: Interlingual errors in the writing of ESL Saudi learners}

the university of Bisha, Al-Namas. The study also attempts to explore particularly which type of errors occur most frequently in the writing samples and accounts for the causes of errors in ESL context with reference to EA and CA of linguistic systems of Arabic and English.

\subsection{Data collection and analysis}

The main samples of the research were essays collected from learners' writing activities inside classrooms and their scripts in the mid and final exams. During the classroom activities, the participants were asked to write some essays on some topics (See samples in the Index). The researcher gave the participants some topics to write on. Later all the gathered writing materials were analyzed to identify the interlingual errors and the errors which were caused due to the different linguistic systems of L1 and L2. The errors later were coded, classified, and quantitatively counted to find what type of error the participants made most frequently. The error analysis in this study followed Corder's (1974) five steps: (a) collection of a sample, (b) identification of errors, (c) description of errors, (d) explanation of errors, and (e) evaluation of errors. The identification of interlingual errors was based on the category of Corder's (1967) taxonomy: grammatical, lexical, semantic, and mechanics errors. Sridhar's (1980) techniques of error analysis were also used. The focus in this study was the analysis of interlingual errors through EA and the errors which were caused by the different linguistic systems of L1 and L2 through CA.

\section{Results and discussion}

This study explored the common errors made by the learners/participants based on the analysis of their writing errors quantitatively and qualitatively. The analysis of errors in this study followed Corder's (1967) taxonomy model which includes grammatical, lexical, semantic, and mechanics errors and attempted to account for the interlingual errors made by the participants. Table 1 showed all types of errors committed by the participants.

Table 1. Type of errors

\begin{tabular}{l|c|l|c|c|c}
\hline Types of Category & & Error Category & Frequency & $\%$ & Rank \\
\hline \multirow{5}{*}{ Grammatical errors (n=226) } & 1 & Verb tense & 56 & 7.52 & 3 \\
\cline { 2 - 6 } & 2 & Word order & 23 & 3.09 & 14 \\
\cline { 2 - 6 } & 3 & Singular and plural & 29 & 3.89 & 10 \\
\cline { 2 - 6 } & 4 & Relative clause & 14 & 1.88 & 18 \\
\cline { 2 - 6 } & 5 & Subject-verb agreement & 37 & 4.97 & 7 \\
\cline { 2 - 6 } & 6 & Subject/Verb drop & 36 & 4.83 & 8 \\
\cline { 2 - 6 } & 7 & Sentence structure & 31 & 4.16 & \multicolumn{2}{|c}{9} \\
\hline Lexical errors $(\mathrm{n}=195)$ & 8 & Noun & 19 & 2.55 & \multicolumn{2}{|c}{16} \\
\hline
\end{tabular}




\section{Fawaz Ali Ahmed Qasem}

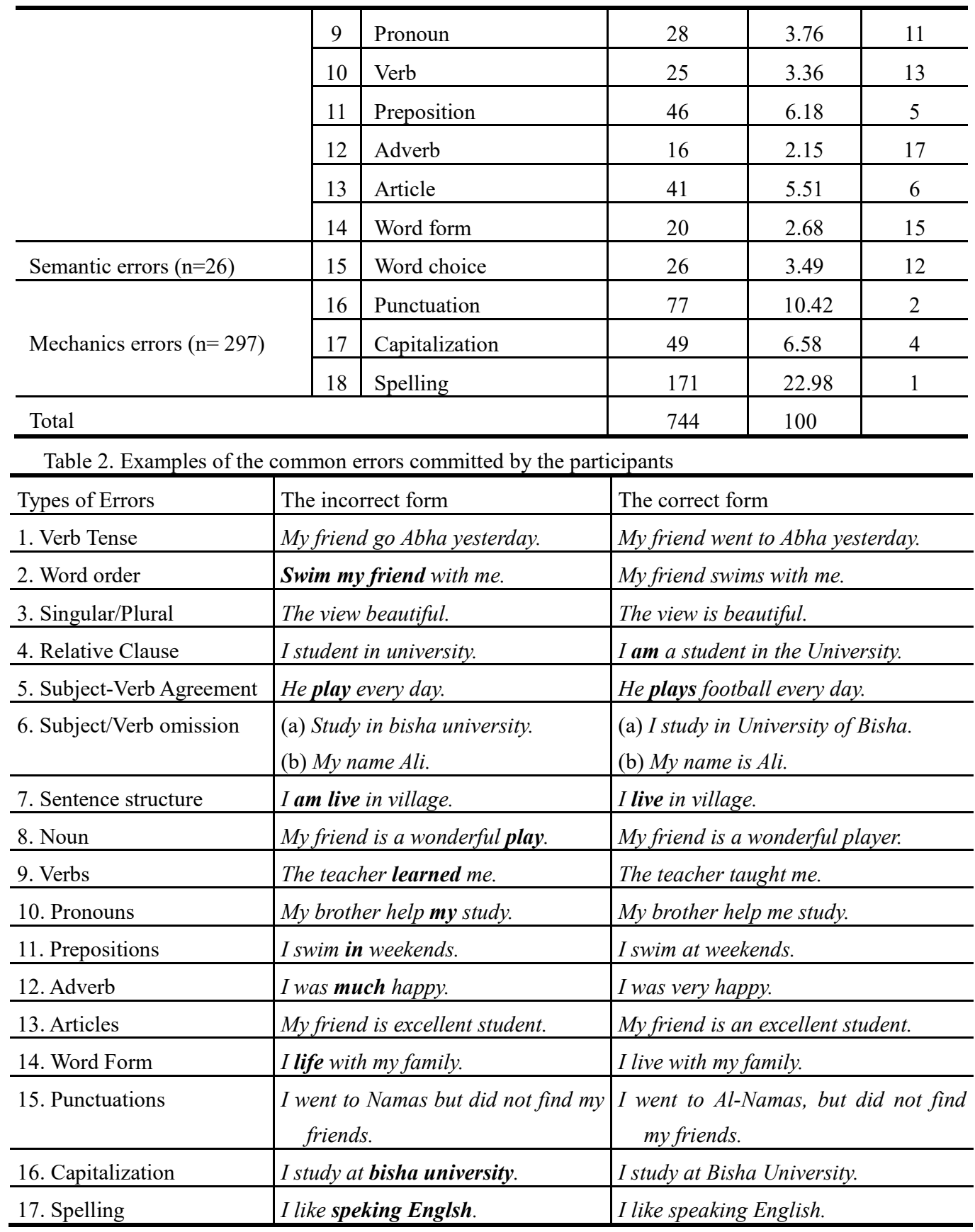

Most of the errors were interlingual - the participants used to overgeneralization and applied their L1 knowledge of rules to L2. Examples of common errors in the data of the 


\section{Crosslingustic Influence of the First Language:}

Interlingual errors in the writing of ESL Saudi learners

participants are given in Table 2.

Table 3 showed that the interlingual and intralingual errors co-exist in the process of learning L2. The study explored that interlingual errors (the influence of Arabic as L1 on learning ESL) were more frequent (54.03\%) than intralingual errors (45.97\%).

Based on the informal observation of the writing tasks/activities and informal interviews with the teachers, it is noticed that learners start making interlingual errors more often than intralingual errors at the early stage of learning L2. Similar findings have been noticed in many various studies on learners of English where learners make interlingual errors more than intralingual errors during acquiring/learning all the elements (Kırkgöz, 2010; Kaweera, 2013; Wu \& Garza, 2014; Al-Qadi, 2017; Long \& Hatcho, 2018; Al-Shahrani, 2018). Some other studies show to some extent that intralingual errors are more frequent depending on the linguistic element, and we can get the data where intralingual errors are more than interlingual errors (Mahmoud, 2005; Khan \& Khan, 2016; Al-Shujairi \& Tan, 2017). The study here showed that most of the morpho-syntactic errors were due to the interference of L1 Arabic on learning ESL.

Table 3. Interlingual and intralingual errors

\begin{tabular}{l|c|c}
\hline Types of errors & Frequency & $\%$ \\
\hline Interlingual errors & 402 & 54.03 \\
\hline Intralingual errors & 342 & 45.97 \\
\hline Total & 744 & 100 \\
\hline
\end{tabular}

Figure 1 also shows more details about all the categories of errors. It was found that students made grammatical errors (30.37\%), lexical errors (26.2\%), semantic errors (3.52\%), and mechanics errors (39.91\%). It is observed that participants had more problems with mechanics errors. Similar findings have been found in another study of ESL Arab learners - Hussain's (2019) analysis of the errors in female Saudi students' writing English essays.

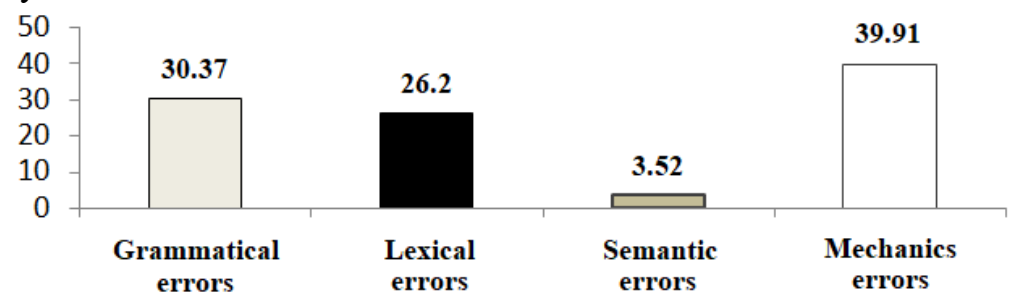

Figure 1. Types of errors

The common interlingual errors seen in the participants' data were dropping subjects and subject inversion as in " go home and "Visit I friend. These types of errors in the corpus are due to the transfer of the syntactic structure of Arabic as L1 of the participants where the 


\section{Fawaz Ali Ahmed Qasem}

structure of dropping subject is allowed. The participants tend to apply the subject drop of Arabic into ESL unconsciously. One of the common interlingual errors in the category of grammatical errors was dropping the be-copular in many writing samples of the participants. Unlike English, Arabic as the mother tongue of the learners allows verbs to be-copular to be dropped. The interference of L1 influenced the learners' writing to use Arabic structure in many situations. Some examples are included in Table 1. Interesting studies with rich and different discussions and claims on verb-be copular omission/drop in Arabic-speaking ESL learners' production exist in the literature (Al-Zahrani, 1993; Diab, 1997; Alshayban, 2012; Dweik \& Othman, 2017).

Similar errors were committed by speakers of other Null Subject Languages (NLs). It has been found (as in, Urdaneta, 2011; Ciesielkiewicz \& Marquez, 2015; Rodríguez, 2018; Courtad \& Courtad, 2019) that Spanish-speaking learners of ESL made basic morphosyntactic errors as a direct influence from L1 to L2 writing including word order, missing the verb "be", and implicit subject. In translation texts from L1 into L2 of Arabic-speaking ESL learners, it is found that Arabic-speaking learners of English make grammatical and lexical errors due to the interference of L1 when it comes to translating the morpho-syntactic categories and structures (as in Ghazala, 1995; Lazim \& Bakir, 2009; Sawalmeh, 2013; Ahamed, 2016; Shamsan \& Attayib, 2016).

Within the lexical errors group, it was found that preposition errors were the most frequent errors and this was due to the interference of Arabic as L1 and the changeable and complex semantic nature of prepositions where one preposition has multiple functions. Many Arab-speaking learners of English tend to use their knowledge and the system of prepositions in Arabic and apply them to English prepositions, as noticed with many studies in similar context (Hamdallah \& Tushyeh, 1993; Lakkis \& Malak, 2000; Fareh \& Saeed, 2009; Hasan \& Abdullah, 2009; Al-Bayati, 2013; Ibrahim, 2017). It is seen that the spelling errors are more frequent in the data here within the mechanics errors group and in many other existing studies in the literature on the writing of the Arabic-speaking learners of English. Most of the errors are interlingual. The learners tend to add, omit, substitute or insert different letters to the words. The spelling errors are attributed to the contrastive orthographic systems of Arabic and English as seen in many studies with almost similar context (Al-Jarf, 2008; Bowen, 2011; Alhaisoni, Al-Zuoud \& Gaudel, 2015; Al-Busaidi \& Al-Saqqaf, 2015; Alenazi, 2018). Punctuation and capitalization errors were also frequent in the data and such type of errors is common in ESL learners' writings, as in Siddiqui's (2015) study conducted in similar context.

One of the interesting issues noticed on the data analysis is that the type of errors varies from one sample to another depending on the level of proficiency. The students with advanced level (with 4-5 overall grade) of proficiency made fewer errors than the learners 


\section{Crosslingustic Influence of the First Language: Interlingual errors in the writing of ESL Saudi learners}

with low level (with 2-3 overall grade) of proficiency. This finding supports the Archibald's (1998) classification study of transfer and the developmental errors in L2 acquisition based on the level of proficiency. The discussion and the informal interview with some teachers supported the fact that the learners of ESL/EFL make interlingual errors. They also highlighted that the different linguistic systems of L1 and L2 play a major role in committing writing errors particularly at the early stage of learning any language as SL and FL. The teachers also stressed on the motivation aspect of learning L2 which has its share on bringing good outcomes of learning.

\section{Findings and suggestions to minimize the interlingual errors}

The results of the study revealed that most of the writing errors in Arabic-speaking learners of ESL at Bisha University, Saudi Arabia, are inter-lingual errors in many components of L2. Arabic interference as the mother tongue of the learners contributes a lot to making such errors. The study also showed that interlingual errors were more frequent than intralingual errors. The common interlingual errors within the syntactic structure errors include tenses errors, dropping the subject errors, dropping verb to be-copular errors, and word order misplacement errors. Within the lexical category, most of the frequent errors found in the data were in prepositions and articles. Spelling errors, as found in many studies mentioned previously, were more frequent in the mechanics error category. The interlingual errors in the writing composition are committed due to the different orthographic, phonological, morpho-syntactic linguistic systems. Cultural differences of L1 and L2 also contributed to the errors especially with the semantic error category.

\subsection{Suggestions to reduce the interlingual errors}

With the emergence of communicative teaching approach and digital technology, it is found that some teachers ignore the analysis of linguistic differences between L1 and L2. Therefore, such type of writing errors found in this study continues for some time in the process of writing of ESL learners. However, teachers of ESL should teach with taking into consideration the importance of CA and EA of the components of L1 and L2. These are some suggestions to help learners avoid making errors and they are summarized as follows:

(a) Collaborative writing is not enough to minimize the interlingual errors. Teachers need to be aware of the linguistic system differences between L1 and L2 and enlighten learners with various tasks and activities about such contrast.

(b) Teachers should highlight the different linguistic systems of L1 and L2 during the teaching of all the skills of $\mathrm{L} 1$.

(c) Learners with comparatively higher interlingual errors should go through remedial programs. This will create the desired awareness necessary for learning SL. 


\section{Fawaz Ali Ahmed Qasem}

(d) Teachers should tactfully use the language learning classes with interesting activities, tasks that broaden learners' awareness and at the same time introduce them to newer information, rules of Second Language/Third Language learning.

(e) A thorough feedback from the teacher during language learning is highly vital and effective to help learners minimize errors and overcome problems related to writing.

(f) Teachers need to assure students that errors are natural and unavoidable while acquiring a second language, and that they are also necessary to understand a new language, and provide them with enough feedback.

(g) Beginners of language learning should be continuously motivated to realize that errors are a part of language learning and should be taken in good stride.

(h) Students' self-assessment and self-correction tasks greatly enable the learners to minimize the errors.

(i) Teachers need to know that writing as a productive skill entails a complex process where learners have different systems of L1 and L2 in addition to the ideas which require formatting and reframing.

For pedagogical implications, similar studies on Error Analysis, either on writing skill or any other skill, are significant as they help teachers to find useful and effective methods of teaching and interesting activities to help learners avoid making more errors. These studies also give importance to Error Analysis and Contrastive Analysis which help teachers make their learners overcome their weakness in writing when discussing the target and the source languages' linguistic differences. In mono-lingual contexts like many countries in the Arab World where English is not spoken widely, such type of study gives hints and feedbacks to the curriculum designers to look closely at the complex and small linguistic differences between L1 and L2 and take into account this issue well while designing the textbooks.

\subsection{Limitations and further studies}

Longitudinal studies of a particular group would give a clearer picture of the nature of the inter-lingual errors. A larger sample would have given stronger claims. It becomes imperative to cover many languages taught as L2 to delve significantly for strong, concrete and plausible evidence with regards to study of error analysis. It would be more fruitful to focus, cover, and examine one component of Second Language to get interesting results within the framework of EA with the support of CA. Studies on EA with experimental and controlled groups on writing composition will give interesting findings.

$\begin{array}{llll}\text { Abbreviations } & & \\ \text { CA } & \text { Contrastive Analysis } & \text { ESL } & \text { English as Second Language } \\ \text { CAH } & \text { Contrastive Analysis Hypothesis } & \text { NSL } & \text { Null Subject Language } \\ \text { EA } & \text { Error Analysis } & \text { SL } & \text { Second Language } \\ \text { FL } & \text { Foreign Language } & & \end{array}$




\section{Crosslingustic Influence of the First Language: Interlingual errors in the writing of ESL Saudi learners}

\section{References}

Ahamed, Y. E. F. 2016. An Investigation of Writing Errors of Saudi EFL University Students [J]. International Journal of Social Science and Humanities Research, 4(2):189-211.

Al-Bayati, W. A. W. T. 2013. Errors Made by Iraqi EFL Undergraduates in the Use of Prepositions [J]. Bulletin of the Transilvania University of Braşov, Series IV: Philology and Cultural Studies, (1):41-56.

Al-Busaidi, S. \& A. Al-Saqqaf. 2015. English Spelling Errors Made by Arabic-Speaking Students [J]. English Language Teaching, 8(7):181-199.

Alenazi, O. S. 2018. Spelling Difficulties Faced by Arab Learners of English as a Foreign Language [J]. Arab World English Journal (AWEJ), 9(2):118-126.

Alhaysony, M. 2012. An Analysis of Article Errors among Saudi Female EFL Students: A case study [J]. Asian Social Science, 8(12):55-66.

Alhaisoni, E., D. R. Gaudel \& K. M. Al-Zuoud. 2017. Article Errors in the English Writing of Saudi EFL Preparatory Year Students [J]. Advances in Language and Literary Studies, 8(1):72-78.

Alhaisoni, E. M., K. M. Al-Zuoud \& D. R. Gaudel. 2015. Analysis of Spelling Errors of Saudi Beginner Learners of English Enrolled in an Intensive English Language Program [J]. English Language Teaching, 8(3):185-192.

Al-Jarf, R. 2008. Phonological and Orthographic Problems in EFL College Spellers [A]. In TELLIS Conference Proceedings [C]. Roudehen: Azad Islamic University.

Al-Jarf, R. 2010. Spelling Error Corpora in EFL [J]. Sino-US English Teaching, 7(1):6-15.

Al-Kahtani, S. A. W. 2002. The Progress of Saudi Students in ESL Literacy: A case study [J]. Linguistica Communication, X1, 1-2.

Alkhudiry, R. I. \& A. A. Al-Ahdal. 2020. Analysing EFL Discourse of Saudi EFL Learners: Identifying mother tongue interference [J]. The Asian ESP Journal, 16(2):9-109.

Almahameed, Y. S. \& M. Al-Shaikhli. 2017. Understanding Syntactic and Semantic Errors in the Composition Writing of Jordanian EFL Learners [J]. International Journal of Applied Linguistics and English Literature, 6(6):158-164.

Al-Qadi, N. S. 1992. The Acquisition of English Derivational Morphology by Arab Speakers: Empirical testing [J]. Language Sciences, 14(2):89-107.

Al-Qadi, N. 1997. Native-Arabic Speakers' Knowledge of English Verb Inflections [J]. Journal of King Abdulaziz University: Education Sciences, 10:3-17.

Al-Shahrani, A. 2004. Error Analysis of Saudi Arabian Writers [D]. Ph.D. Dissertation. Idaho: University of Idaho.

Al-Shahrani, H. M. 2018. Mother Tongue Interference: A study of interlingual errors in the written performance of the EFL preparatory year female students at Al-Baha University in Saudi Arabia [J]. Journal of Human and Social Sciences, 2(2):118-135.

Alshayban, A. S. 2012. Copula Omission by EFL Arab Learners [D]. Ph.D. Dissertation. Fort Collins: Colorado State University.

Al-Shujairi, Y. B. J. \& H. Tan. 2017. Grammar Errors in the Writing of Iraqi English Language Learners [J]. International Journal of Education and Literacy Studies, 5(4):122-130.

Al-Sindy, H. 1994. Analysis of Syntactic Interference Errors in the Writing of English by Saudi Adult Students [OL]. ProQuest Dissertations and Theses Global. Retrieved from: http://search.proquest.com/docview/ 304136640 ?accountid=30902.

Al-Zahrani, M. 1993. Copula Omission and Retention by Arab Learners of English [D]. MA Thesis. South Carolina: University of South Carolina.

Al-Zoubi, D. M. \& M. A. Abu-Eid. 2014. The Influence of the First Language (Arabic) on Learning English as a Second Language in Jordanian Schools, and Its Relation to Educational Policy: Structural errors [J]. Sino-US English Teaching, 11(5):355-372.

A-Qadi, M. M. 2017. English Article System Errors among Saudi Arab EFL Learners: A case of the preparatory year english program learners of King Saud University [J]. Language and Translation, 5(1): 69-77. 


\section{Fawaz Ali Ahmed Qasem}

Archibald, J. 1998. Second Language Phonology [M]. Amsterdam/ Philadelphia: John Benjamins Publishing Company.

Bowen, H. 2011. Spelling It out! Accounting for Spelling Difficulties for Arab Learners of English [A]. In D. Anderson \& R. Sheehan (eds.). Foundations for the Future: Focus on vocabulary: Emerging theory and practice for adult Arab learners [C]. Abu Dhabi: HCT Press, 85-98.

Brown, D. 2000. Principles of Language Learning and Teaching, 4th ed [M]. New York: Longman.

Brown, H. D. 1993. Principles of Language Learning and Teaching [M]. San Francisco: Prentice Hall Regents.

Ciesielkiewicz, M. \& E. Marquez. 2015. Error Analysis and Its Relevance to Teaching ESL Composition [J]. International Journal of Linguistics, 7(5):1-15.

Corder, S. 1967. The Significance of Learners' Errors [J]. International Review of Applied Linguistics. 5(4):161-169.

Corder, S. P. 1974. Error Analysis [A]. In J. P. B. Allen \& S. P. Corder (eds.). Techniques in Applied Linguistics (The Edinburgh Course in Applied Linguistics, 3) [C]. Oxford: Oxford University Press, 122-154.

Courtad, J. C. \& C. A. Courtad. 2019. The Use of English Grammar and the Confidence Level of the Student when Writing in Spanish [J]. The Journal for Research and Practice in College Teaching, 4(1):170-191.

Diab, N. 1997. The Transfer of Arabic in the English Writings of Lebanese Students [J]. The ESPecialist, 18(1):71-83

Dulay, H., M. Burt \& S. Krashen. 1982. Language Two [M]. New York: Oxford University Press.

Dweik, B. S. \& Z. A. Othman. 2017. Lexical and Grammatical Interference in the Translation of Written Texts from Arabic into English [J]. Academic Research International, 8(3):65-70.

Ellis, R. 1985. Understanding Second Language Acquisition [M]. Oxford: Oxford University Press.

Ellis, R. 1997. Second Language Acquisition [M]. Oxford: Oxford University Press.

Fareh, S. \& A. T. Saeed. 2009. Problems Arab EFL Students Encounter in Learning Prepositions [J]. International Journal of Arabic-English Studies, 10(1):93-112.

Fehri, A. F. 1993. Issues in the Structure of Arabic Clauses and Words [M]. Dordrecht: Kluwer.

Gass, S. M. \& L. Selinker. 1983. Language Transfer in Language Learning. Issues in Second Language Research [M]. Rowley: Newbury House Publishers, Inc.

Ghazala, H. 1995. Translation as Problems and Solutions. A Course Book for University Students and Trainee Translators [M], Syria: Malta: ELGA Publication.

Hacohen, A. \& J. Schaeffer. 2007. Subject Realization in Early Hebrew/English Bilingual Acquisition: The role of crosslinguistic influence [J]. Bilingualism, 10(3):333.

Hamdallah, R. \& H. Tushyeh. 1993. A Contrastive Analysis of Selected English and Arabic Prepositions with Pedagogical Implications [J]. Papers and Studies in Contrastive Linguistics, 28(2):181-190.

Harmer, J. 1983. The Practice of English Language Teaching [M]. London: Longman.

Hasan, A. A. \& I. H. Abdullah. 2009. A Comparative Study of English and Arabic Use of Prepositions amongst Arab Native Speakers [Z]. Ms. Selangor: Universiti Kebangsaan Malaysia.

Holmberg, A. 2010. Null Subject Parameters. Parametric Variation: Null subjects in minimalist theory [A]. In T. Biberauer, A. Holmberg, I. Roberts \& M. Sheehan (eds.). Parametric Variation: Null subjects in minimalist theory [C]. Cambridge: Cambridge University Press, 88-124.

Hubbard, P., H. Jones, B. Thornton \& R. Wheeler. 1983. A Training Course for TEFL [M]. Oxford: Oxford University Press.

Hussain, R. A. M. 2019. An Analysis of Undergraduate Saudi EFL Female Students' Errors in Written English Essays [J]. Arab World English Journal, (1):241-258.

Ibrahim, A. A. M. 2017. The Difficulties Encounter (ESP) Students in Using English Prepositions of Time [J]. International Journal of Humanities Social Sciences and Education (IJHSSE), 4(11):214-222.

Kaweera, C. 2013. Writing Error: A review of interlingual and intralingual interference in EFL context [J]. English language teaching, 6(7):9-18.

Kazazoğlu, S. 2020. The Impact of L1 Interference on Foreign Language Writing: A contrastive error analysis [J]. Dil ve Dilbilimi Çalışmaları Dergisi, 16(3):1168-1188. 


\section{Crosslingustic Influence of the First Language: Interlingual errors in the writing of ESL Saudi learners}

Khan, S. R. \& M. R. Khan. 2016. Error Analysis in English writing [J]. International Multidisciplinary Research Journal, 4(2):232-243.

Khatter, S. 2019. An Analysis of the Most Common Essay Writing Errors among EFL Saudi Female Learners (Majmaah University) [J]. Arab World English Journal, 10(3):364-381.

Kırkgöz, Y. 2010. An Analysis of Written Errors of Turkish Adult Learners of English [J]. Procedia-Social and Behavioral Sciences, 2(2):4352-4358.

Lakkis, K. \& M. A. Malak. 2000. Understanding the Transfer of Prepositions: Arabic to English [OL]. Retrieved from http://www.languageinindia.com/april2010/mahendrandissertation.pdf.

Lado, R. 1957. Linguistic Across Cultures [M]. Ann Arbor: University of Michigan Press.

Larsen, D. \& M. H. Long. 1992. An Introduction to Second Language Acquisition Research [M]. London: Longman.

Long, R. \& Y. Hatcho. 2018. The First Language's Impact on L2: Investigating Intralingual and Interlingual Errors [J]. English Language Teaching, 11(11):115-121.

Liu, M. \& Y. Xu. 2013. An Investigation of Syntactic Errors in Chinese Undergraduate EFL Learners' Compositions: A cohort study [J]. International Journal of Applied Linguistics and English Literature, 2 (4):182-191.

Mahmoud, A. 2005. Collection Errors Made by Arab Learners of English [J]. Asian EFL Journal, 6(2):116-126.

Mourssi, A. 2013. Crosslinguistic Influence of L1 (Arabic) in Acquiring Linguistic Items of L2 (English): An Empirical Study in the Context of Arab Learners of English as Undergraduate Learners [J]. Theory and Practice in Language Studies, 3(3):397-403.

Lazim, H. G. \& K. H. Bakir. 2009. Stylistic Problems Confronting Arab Students in Arabic-English Translation [J]. Adab Al-Basrah, 50:24-41.

Lghzeel, F. A. \& N. R. M. Radzuan. 2020. The Cross-Linguistic Influence of Arabic on the English Passive Voice [J]. Global Journal of Foreign Language Teaching, 10(3):182-190.

Noor, H. H. 1994. Some Implications of the Role of the Mother Tongue in Second Language Acquisition [J]. Linguistica Communicatio, 6:97-106.

Nuruzzaman, M., A. S. Islam \& I. J. Shuchi. 2018. An Analysis of Errors Committed by Saudi Non-English Major Students in the English Paragraph Writing: A study of comparisons [J]. Advances in language and literary studies, 9(1):31-39.

Odlin, T. 1989. Language Transfer (Vol. 27) [M]. Cambridge: Cambridge University Press.

Qasem, F. 2014. The Acquisition of Yemeni Ibbi Arabic: The development of verbal morphology and overt subject realization $[\mathrm{D}]$. Ph.D. Dissertation. Hyderabad: The English and Foreign Languages University.

Qasem, F. 2020. Exploring Spelling Errors with Relation to the Phonological Syllable Structure in the Writings of Saudi ESL Learners [J]. International Journal of English Linguistics, 10(6):152-161.

Richards, J. C. 1974. Error Analysis: Perspective on second language acquisition [M]. London \& New York: Routledge.

Richards, J. C. \& R. W. Schmidt. 2002. Longman Dictionary of Language Teaching and Applied Linguistics [M]. London \& New York: Routledge.

Rodríguez, C. T. 2018. The Influence of the Spanish Language in the Learning of English for Secondary Education Students [J]. EntreLinguas, 4(2):251-267.

Saeed, F. 2011. The Syntax of Verbal Agreement in Minimalism: Formal feature valuation in English and Standard Arabic [D]. Ph.D. Dissertation. Hyderabad: EFL University.

Sawalmeh, M. H. M. 2013. Error Analysis of Written English Essays: The case of students of the preparatory year program in Saudi Arabia [J]. English for Specific Purposes World, 14(40):1-17.

Selinker, L. 1972. Interlanguage [J]. International Review of Applied Linguistics in Language Teaching, 10 (3):209-231.

Shamsan, M. \& A. M. Attayib. 2016. Investigating Morpho-Syntactic Translation Errors Made by Yemeni EFL Students [J]. Arab World English Journal (AWEJ), Special Issue on Translation, (5):281-298.

Siddiqui, M. A. 2015. Evaluating Capitalization Errors in Saudi Female Students' EFL Writing at Bisha University [J]. Arab World English Journal (AWEJ), 6(1):232-250.

Sridhar, S. N. 1980. Contrastive Analysis, Error Analysis, and Interlanguage [A]. In J. Fisiak (ed.). 


\section{Fawaz Ali Ahmed Qasem}

Contrastive Linguistics and the Language Teacher [C]. Oxford: Pergamon Press.

Urdaneta, J. L. L. 2011. Spanish-English Writing Structure Interferences in Second Language Learners [J]. Gist: Education and Learning Research Journal, (5):158-179.

Wu, H. P. \& E. V. Garza. 2014. Types and Attributes of English Writing Errors in the EFL Context-A Study of Error Analysis [J]. Journal of Language Teaching and Research, 5(6):1256-1262.

Younes, Z. B. \& F. S. Albalawi. 2015. Exploring the Most Common Types of Writing Problems among English Language and Translation Major Sophomore Female Students at Tabuk University [J]. Asian Journal of Basic and Applied Sciences, 3(2):7-26. 